\title{
Immunohistochemical demonstration of prostaglandin E-2 in preimplantation mouse embryos
}

\author{
S. Niimura and K. Ishida \\ Department of Animal Science, Faculty of Agriculture, Niigata University, Ikarashi, \\ Niigata 950-21, Japan
}

\begin{abstract}
Summary. An antiserum to prostaglandin (PG) E-2 and indirect immunofluorescence were used to demonstrate immunohistochemically the presence of PGE-2 in preimplantation mouse embryos. Fluorescence was observed in the cytoplasm of unfertilized 1-cell embryos to the blastocyst stage. The strongest fluorescence was detected at the 8-cell and morula stages. In embryos cultured from the 2-cell stage on, the fluorescence was observed in the cytoplasm of 4-cell embryos to the blastocyst stage. No differences were observed in the intensity and the distribution of the fluorescence between embryos in vivo and those in vitro. However, when blastocysts were cultured in a medium containing $100 \mu \mathrm{M}$-indomethacin, the fluorescence was diminished markedly. We therefore suggest that preimplanted mouse embryos contain PGE-2 during their early developmental stages and that the embryos synthesize the PGE-2.
\end{abstract}

\section{Introduction}

The detection of prostaglandins (PGs) in mammalian embryos was first reported by Dickmann \& Spilman (1975). They detected, by radioimmunoassay (RIA), PGE-A and PGF in rabbit blastocysts $144 \mathrm{~h}$ post coitum and suggested that the embryos had the ability to synthesize the PGs. PGs have since been detected by RIA in blastocysts of rabbits (Dey et al., 1980; Pakrasi \& Dey, 1982; Harper et al., 1983), cows (Shemesh et al., 1979; Lewis et al., 1982), ewes (Lacroix \& Kann, 1982; Hyland et al., 1982) and sows (Davis et al., 1983).

While the exact function of the embryonic PGs is unknown, PGs in blastocysts have been considered to participate in the process of implantation (Pakrasi \& Dey, 1982). It has also been reported that PGE-2 has a major role in the hatching of mouse blastocysts (Baskar et al., 1981) and is able to induce implantation of mouse blastocysts (Holmes \& Gordashko, 1980). However, the detection of PGs was only possible for blastocysts which are of a size suitable for RIA, and PGs have not been measured in unfertilized eggs and embryos at cleavage stages.

This investigation was designed to demonstrate immunohistochemically whether PGE-2 is present in mouse embryos at various developmental stages, and to explore the possibility of PGE-2 synthesis in the embryos.

\section{Materials and Methods}

Animals and collection of embryos. ICR female mice, 8 weeks old, were superovulated with 5 i.u. PMSG (Teikokuzoki, Tokyo, Japan), and with 5 i.u. hCG (Teikokuzoki) injected $48 \mathrm{~h}$ later. They were mated with ICR males of proven fertility. The embryos were collected at the following times by flushing oviducts or uteri with culture medium (Whittingham, 1971); $24 \mathrm{~h}$ after hCG injection to obtain pronuclear embryos; $48 \mathrm{~h}$ for 2 -cell embryos; $60 \mathrm{~h}$ for $4 \mathrm{cell}$ embryos; $67 \mathrm{~h}$ for 8-cell embryos; $80 \mathrm{~h}$ for morulae and $96 \mathrm{~h}$ for blastocysts. Unfertilized eggs were also collected from the oviducts of unmated females at $24 \mathrm{~h}$ after hCG injection.

Culture of embryos. Two-cell embryos from superovulated mice were collected from the oviducts into culture medium (Whittingham, 1971) containing 0.4\% bovine serum albumin (Sigma, St Louis, MO, U.S.A.). The embryos 
were cultured for $48 \mathrm{~h}$ in the medium mentioned above in a humidified atmosphere of $5 \% \mathrm{CO}_{2}$ and $95 \%$ air at $37^{\circ} \mathrm{C}$, and were examined at the 4-cell, 8-cell, morula and blastocyst stages. Blastocysts cultured from the 2-cell stage in medium containing $100 \mu \mathrm{M}$-indomethacin were also examined. A stock solution of $10 \mathrm{~mm}$-indomethacin was prepared by dissolving indomethacin (Wako, Osaka, Japan) in $100 \%$ ethanol. This solution was diluted with the culture medium to $100 \mu \mathrm{M}$. As a control, blastocysts cultured from the 2-cell stage in an indomethacin-free medium with ethanol were observed.

Indirect immunofuorescence assay. Embryos developed in vivo and in vitro were washed twice with phosphatebuffered saline (PBS) (Dulbecco \& Vogt, 1954), slightly modified and the zonae pellucidae were removed in $0.2 \%$ pronase (Sigma) in PBS. The composition of the PBS was $8.0 \mathrm{~g} \mathrm{NaCl}, 0.2 \mathrm{~g} \mathrm{KCl}, 1.15 \mathrm{~g} \mathrm{Na}_{2} \mathrm{HPO}_{4}, 0.2 \mathrm{~g} \mathrm{KH}_{2} \mathrm{PO}_{4}$ and $1000 \mathrm{ml}$ water. The naked embryos were washed again in PBS and fixed in $10 \%$ formalin-PBS for $60 \mathrm{~min}$ at room temperature. They were further washed 3 times in PBS for $60 \mathrm{~min}$ in all and incubated in the rabbit anti-PGE-2 serum (Polysciences, Warrington, PA, U.S.A.) for $60 \mathrm{~min}$. The anti-PGE-2 serum was diluted with PBS to 100 times. All these procedures were carried out in a moist chamber at room temperature. The antiserum to PGE-2 reacts with PGE-2 (100\%), 15-keto-PGE-2 (13.2\%), PGE-1 (6.5\%), 13,14-dihydro-PGE-2 (2.1\%), 13,14-dihydro-15-ketoPGE-2 $(0.6 \%)$ and $<0.3 \%$ with the A, B, D or F series of PGs. The embryos were washed again in PBS for 60 min and then incubated in the goat anti-rabbit IgG conjugated with fluorescein (Cappel, West Chester, PA, U.S.A.) for $60 \mathrm{~min}$. The goat anti-rabbit IgG conjugated with fluorescein was diluted with PBS to 64 times. The control embryos were incubated in normal rabbit serum (1:100) before the fluorescein treatment, or in the fluorescein conjugate only. The same procedures of assay were applied 3 times to $30-45$ embryos at every stage. The embryos were placed in a small amount of PBS on glass slides to be observed, and were photographed under a reflected-light fluorescing microscope (Olympus, Tokyo, Japan) equipped with HBO-200 (Osram, München, West Germany) as an ultraviolet light source (exposures of $2 \mathrm{~min}$ ).

\section{Results}

\section{Embryos in vivo}

Fluorescence was observed in the cytoplasm of all these embryos from the unfertilized 1-cell through to the blastocyst stage (Fig. 1). The fluorescence was not observed in the embryos incubated in normal rabbit serum or in fluorescein conjugate only. When positive, the fluorescence was spread evenly throughout the cytoplasm, although its intensity was not even in the blastomeres. In blastocysts, while the intensity of the fluorescence varied amongst the cells in both the inner cell mass and the trophoblast, there was no difference in the distribution of the fluorescence in the two cell types. The intensities of the fluorescence in the embryos at various developmental stages are shown in Table 1. The intensity of fluorescence was weak in the embryos at the 1-cell stage, a bit stronger in those at the 2-cell and 4-cell stages, strongest at the 8-cell and morula stages, and slightly weaker again at the blastocyst stage. No differences were observed in the intensity of fluorescence between unfertilized eggs and pronuclear embryos at the 1-cell stage.
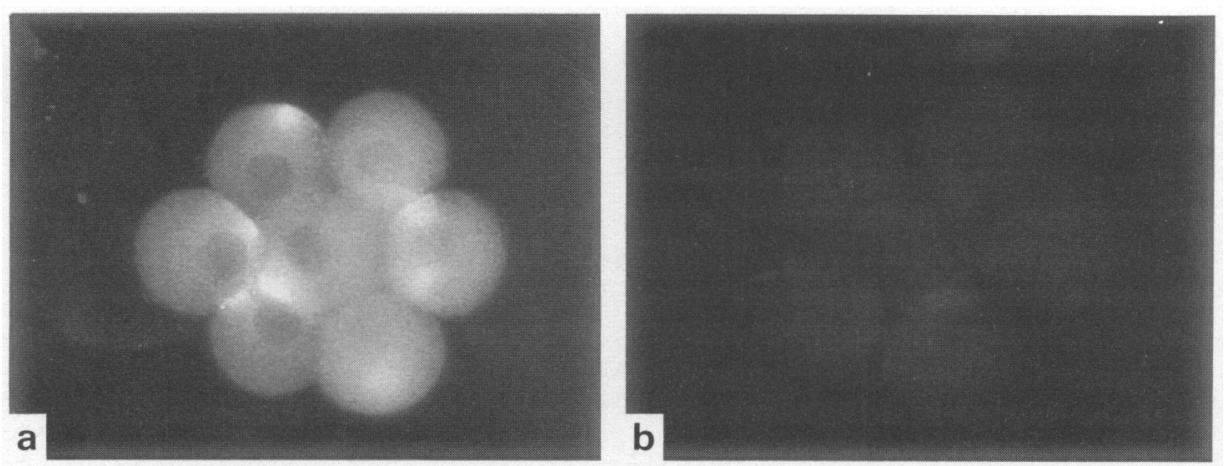

Fig. 1. Fluorescence showing the presence of PGE-2 in each blastomere of an 8-cell mouse embryo (a) and its absence in a control 8-cell mouse embryo treated only with the FITCconjugated anti-rabbit IgG (b). $\times 400$. 
Table 1. Intensity of fluorescence in mouse embryos

\begin{tabular}{lccccccc}
\hline & \multicolumn{7}{c}{ Developmental stages } \\
\cline { 2 - 7 } Embryos & Unfertilized & Pronuclear & 2-Cell & 4-Cell & 8-Cell & Morula & Blastocyst \\
\hline $\begin{array}{lcccccc}\text { In vivo } \\
\text { In vitro }\end{array}$ & + & + & ++ & ++ & +++ & +++ & ++ \\
\hline
\end{tabular}

The symbols,+++ and +++ represent weak, moderate and strong fluorescence, respectively.

Table 2. Intensity of fluorescence in mouse blastocysts cultured from the 2-cell stage in a medium with $100 \mu \mathrm{M}$-indomethacin

\begin{tabular}{lccccc}
\hline & \multirow{2}{*}{$\begin{array}{c}\text { No. of } \\
\text { blastocysts } \\
\text { observed }\end{array}$} & \multicolumn{3}{c}{ Intensity of fluorescence } \\
\cline { 3 - 6 } & & Moderate & Weak & None \\
\hline Indomethacin-free & 34 & $30^{*}$ & 4 & 0 \\
Indomethacin-containing & 35 & & $9^{*}$ & 22 & 4 \\
\hline${ }^{*} P<0.001$ by $\chi^{2}$ test. & & & & &
\end{tabular}

\section{Embryos in vitro}

Fluorescence was observed in the cytoplasm of embryos in vitro at the 4-cell through to blastocyst stages. Its intensity and distribution were similar to those of embryos in vivo (Table 1).

The intensities of fluorescence in blastocysts cultured from the 2-cell stage in the medium containing indomethacin are shown in Table 2. In blastocysts cultured in an indomethacin-free medium, 30 out of 34 embryos showed a moderate intensity of fluorescence, while the rest exhibited only weak fluorescence. Significantly fewer blastocysts cultured in the indomethacin-containing medium exhibited moderate fluorescence.

\section{Discussion}

The results from the present experiments prove for the first time the presence of PGE- 2 in mouse embryos, not only at the blastocyst stage but at all the stages from the 1-cell to the morula. Because the PGE-2 was detected in the embryos developed in vitro and because that in blastocysts was markedly reduced by indomethacin, an inhibitor of PG synthesis, we conclude that preimplantation mouse embryos have synthesized the PGE-2 they contain. Racowsky \& Biggers (1983), however, failed to demonstrate PGs or PG synthesis from arachidonic acid in mouse blastocysts in vitro. The discrepancy may be due to the sensitivity of the methods used to detect the PGs.

From the fluctuations in the fluorescence intensities in the present experiments, it is considered that the PGE-2 content in mouse embryos is greatest at the 8-cell and morula stages. This agrees with the results obtained by Niimura \& Ishida (1978) who detected histochemically the presence of 15-hydroxy PG dehydrogenase, a major enzyme metabolizing PGs to less active metabolites, in hamster embryos up to the 8-cell stage only. Large amounts of PGE-2 in 8-cell embryos and morulae may play roles in the hatching (Baskar et al.,1981) and implantation (Holmes \& Gordashko, 1980) of blastocysts.

It has been reported that $\Delta^{5}-3 \beta$-hydroxysteroid dehydrogenase, a key enzyme of steroid biosynthesis, can be detected histochemically in preimplantation mouse embryos (Dickmann et al., 1976; Niimura \& Ishida, 1980) and biosynthesis of some steroid hormones in preimplantation mouse embryos can therefore be presumed. We conclude that the PGE-2 demonstrated in the present experiments may act as a mediator in mouse embryo steroidogenesis. 


\section{References}

Baskar, J.F., Torchiana, D.F., Biggers, J.D., Corey, E.J., Andersen, N.H. \& Subramanian, N. (1981) Inhibition of hatching of mouse blastocysts in vitro by various prostaglandin antagonists. J. Reprod. Fert. 63, 359-363.

Davis, D.L., Pakrasi, P.L. \& Dey, S.K. (1983) Prostaglandins in swine blastocysts. Biol. Reprod. 28, $1114-1118$.

Dey, S.K., Chien, S.M., Cox, C.L. \& Crist, R.D. (1980) Prostaglandin synthesis in the rabbit blastocyst. Prostaglandins 19, 449-453.

Dickmann, Z. \& Spilman, C.H. (1975). Prostaglandins in rabbit blastocysts. Science, N.Y. 190, 997-998.

Dickmann, Z., Dey, S.K. \& Gupta, J.S. (1976) A new concept: control of early pregnancy by steroid hormones originating in the preimplantation embryo. Vitams Horm. 34, 21 5-242.

Dulbecco, R. \& Vogt, M. (1954) Plaque formation and isolation of pure lines with poliomyelitis viruses. $J$. exp. Med. 99, 167-182.

Harper, M.J.K., Norris, C.J. \& Rajkumar, K. (1983) Prostaglandin release by zygotes and endometria of pregnant rabbits. Biol. Reprod. 28, 350-362.

Holmes, P.V. \& Gordashko, B.J. (1980) Evidence of prostaglandin involvement in blastocyst implantation. J. Embryol. exp. Morph. 55, 109-122.

Hyland, J.H., Manns, J.G. \& Humphrey, W.D. (1982) Prostaglandin production by ovine embryos and endometrium in vitro. J. Reprod. Fert. 65, 299-304.
Lacroix, M.C. \& Kann, G. (1982) Comparative studies of prostaglandins $F_{2 \alpha}$ and $E_{2}$ in late cycle and early pregnant sheep: in vitro synthesis by endometrium and conceptus effects of in vivo indomethacin treatment on establishment of pregnancy. Prostaglandins 23, 507-526.

Lewis, G.S., Thatcher, W.W., Bazer, F.W. \& Curl, J.S. (1982) Metabolism of arachidonic acid in vitro by bovine blastocysts and endometrium. Biol. Reprod. 27, $431-439$.

Niimura, S. \& Ishida, K. (1978) Histochemical studies of prostaglandin dehydrogenase in hamster eggs. Jap. $J$. Anim. Reprod. 24, 16-18.

Niimura, S. \& Ishida, K. (1980) Histochemical studies of hydroxysteroid dehydrogenases in tubal eggs of mice, rats and guinea pigs. Jap. J. Anim. Reprod. 26, 89-93.

Pakrasi, P.L. \& Dey, S.K. (1982) Blastocyst is the source of prostaglandins in the implantation site in the rabbit. Prostaglandins 24, 73-77.

Racowsky, C. \& Biggers, J.D. (1983) Are blastocyst prostaglandins produced endogenously? Biol. Reprod. 29, 379-388.

Shemesh, M., Milaguir, F., Ayalon, N. \& Hansel, W. (1979) Steroidogenesis and prostaglandin synthesis by cultured bovine blastocysts. J. Reprod. Fert. 56, 181-185.

Whittingham, D.G. (1971) Culture of mouse ova. $J$. Reprod. Fert., Suppl. 14, 7-21.

Received 16 October 1986 